$\overline{\overline{\text { 屡望 }}}$

\title{
繊維衣料品業界における流通情報ネットワーク システムの検討
}

伊沢武

1.はじめに

激動の 1970 年代と世間では呼称されるように，世の 中はハート的思考からンフト的思考へと急速に变化して いる。これがいわゆる脱工業化社会, 情報化社会という ものと解积されている様であるが，その実態は果してど うであろうか。

産業構造における知識集約化，およびュンピュータリ せーション等の現状は必ずしも着実な段階にあるとはい いきれない。その証拠に公害, 高過密, 人間性の荒廃等 の事象が大きな壁となって進路に立ちはだかっている。 すなわちもとを直せば，全て情報の過多，情報のスプ ロール化, 情報に対する盲目性等, 情報公害に起因する ものも大いに考えられよう。

最近, 脱工業化のもとに重視されている流通問題につ いても，情報のコントロールなくしては，適正なる流通 活動を行なうことは不可能といわれ，流通関㐿の情報シ ステムの開発がしきりに行なわれている。社会全体の活 動はすべて情報によってコントロールされるといっても 過言ではないのではないかと思われる次第である。

本誌Vol. 5，No.9号の技術動向記事において，瀻維 業界はテキスタイル産業からファッション産業への移行 であり生産者が作り与えたものを消費者が貿う時代から， 消費者が要求するものを生産者が作る時代に变りつつあ るとあったが，まさにその通りであり，その場合に根底 に流れるものの重要な要素として，倩報というものが焦 置の的になるはずである。

当然産業界に扔いて，ィーカーから小壳業までの各企 業は必死になって情報をさがし求め，その情報活用のた めにシステム化を図り，情報コントロールのためのンフ トゥェフ開発にとり組もうとしている事はいうまでもな い事であろう。

\footnotetext{
TAKESHI ISAWA

（財団法人）流通システム開発せンター 研究開発部研究員
}

しかしここで考えてみたい事は，たとえば道路である が，現在の道路は国道以外は地方自治体に上る管理とな つている。しかし道路管理上の問題点の一つである自勤 車公害，交通䜤帯等に対するコントロールは，物を単緇 に管理すれば良いといら対象にはなり得ない。交通情報 センター等忏そのための一つの手段であると思うが,こ の例からもわかる様に活動の裹には必す情報が発生して 掞り，この情報を無視しては，適正なるコントロールが， 決して望めないという事をものがたっているのてはない だろらか。

話をもとにもどすが，同じ様に㡸業界の各企業の活動 の裏には必ず情報があり，この情報のコントロールが重 要なカギとなるのである。

しかし情報には個別企業レベルによってコントロール できるものと，できないものとがあり，後者の場合には 個別企業外の何者かによって解決されなければならない。 この機能がなくしては，各企業において進められている 合理化, システム化等も当然ある限界の範囲にとじこめ られるし，まして国家を举げての情報化社会形成等は望 むべくもない。

ここに我々は強く必要性を感じ，焦点をあて，情報ネ ットワークの檕築という大事業を打ち立てているのであ る。特に当初研究の課題として, 産業別情報ネットワー ク，また别の角度からの分類による流通適正化を图るた めの産業別流通情報ネットワークシステムの構筑といら 枠て，通産行政における流通情報センタ一設置を志向す る国家プロジゥクの中での研究事業に今年度は特に国 民産業的比率の高い絨維衣料品業界を背景に着手した次 第である。

2. 流通，流通情報，流通情報ネットワーク とは

流通とはなど，今さらいうまでもないし珫者諸兄に失 礼であるので詳しい説明は省略させて盾くが，ここて特 に前提条件としていっておきたいのは，広義の流通とい 
う定義である。すなわち生産から消费までを大きく包括 して考えていることである。

その中での流通情報とは，直接間接にかかわらず流通 適正化に笴与しうる情報であり，その情報の中でとりあ げたい情報の定義住次のように限定している。

(1) 記録情報（何らかの形で記録された情報）

(2) 外部情報（事業体間で交換できる汎用情報）

最近コンピュータの普及率が高いせいが，何気なしに 情報といらと，すぐコンピュ一タ関連の情報にむすびつ けて解秎される傾向にあるが、これは䛊りである。つま りここでいら情報とは，定性的，定量的を問わない文献 情報，文畫情報等も含んだもので考えてよい。

このよらな情郝のネットワークを組むことにより適正 な流通活動の発展を望むべく考える訳で，当然ネットワ ークとはという設問に対しては次の分類によって答える ことにする。

(1) システム構成による体系

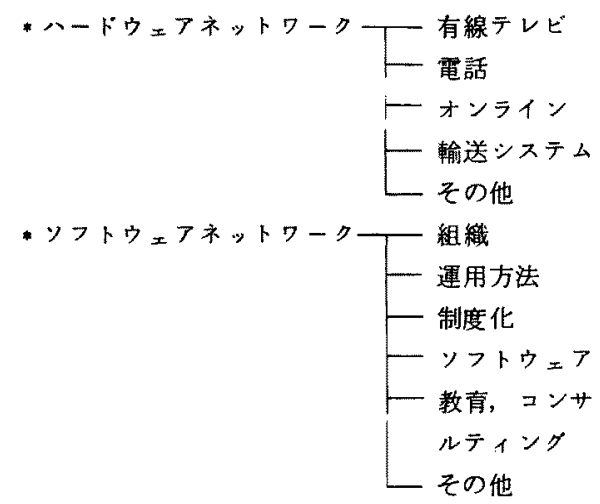

(2) レデル付けによる体系

*インタナショナル総合ネットワーク

*インタナショナル分類別ネットワーク

・国家レヘル総合ネットワーク

*国家レベル分類別ネットワーク

・地域レベル総合ネットワーク（地域間）

*地域レぶル分類ネットワーク（地域間）

(3) 機能別による体系

*行政情報ネットワーク

，交通情報ネットワーク

＂流通情報ホットワーク

，科学技術情報ネットワーク

・レジャー情報ネットワーク

一貿易情報ネットワーク

“市場箐報ネットワーク

•その地

(4) 業界別，物資別に上る体系
*瀻維衣料品 $\left[\begin{array}{l}\text { ファッション商品 } \\ \hline \text { ステープル商品 }\end{array}\right.$

*食品

*医薬品

*酒類，その他

3. 流通システム化と流通情報ネットワーク

昭和 46 年, 流通システム化推進会議が「流通システ ム化基本方針」を吐表して以来，流通システム化は全て の流通諸問題解決の決め手として，各方面で進められて いるところであるが，本来，流通活動とは生産活動から 消費活動までのブロセスを媒介することから，多数の企 業，事業体間にわたるものであり，一企業または，一事 業体のみで考えた流通システム化では当然限界が生じる。

また，昭和 50 年度を目標とした流通予測に扔いても， 情報が今の 5 倍に達するとあり，情報洪水も生じか子小な いことや，情報面に㧍ける企業格差, 地域格差を大きく することは，適正なる，また均衡ある流通活哩の発展に 大きなマイナスになることはたやすく予測される。

個別企業の立場にあっても，流通システム化の限界が あらわれ，より高度な流通システム化ビションへのアプ ローチは阻止されてしまう。

このような意味から企業間, 事業体間にわたる,より 広い拡がりをもった「流通情報ネットロークの構筑が急 務であり，流通システム化と切っても切れない位置付け の中での流通情報ネットワークシステムの必要性が存在 しているのである。

4. 流通情報ネットワークシステムの フレームワーク

それでは，流通情報ネットワータシステムとは，どの ようなものが創造されるのであろう。第6因は現在の我 々の研究過程の中で考えられたイメーシ，すなわちフレ ームワークであるがこれ标次のように説明されよう。

業果の中にネットワークをいかに位熼させるか，また その位置付けられた中でどのよらな機能をもつべきか。

このホットワークの中心となる情報センターの役割は どうあるべきか，等が中心課題であり，その構筑対象は 次のように考えられる。

(1) 情報の体系化 (データパンク)

（2）情報収集ネットワークシステム

(3) 情報センターの設立

(4) 情報運用 (提供)ネットワータシステム

(5) 情報活用のためのソフトウェフ

(6) 情報利用技街と教育事業

この6項目が詳細に設計され，構築されたネットワー 


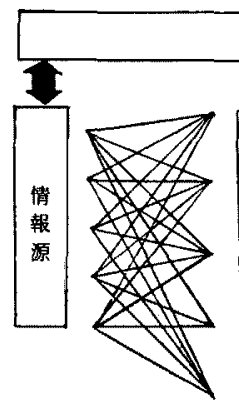

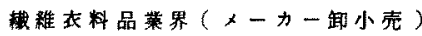
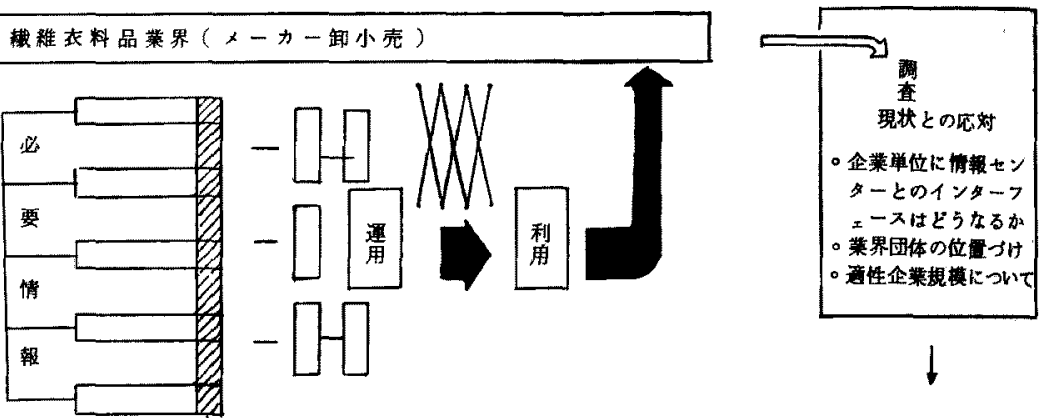

\begin{tabular}{|c|c|c|c|c|}
\hline 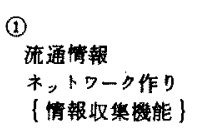 & $\begin{array}{l}\text { (2) } \\
\text { 悄報の体系化 } \\
(\text { 一元化 })\end{array}$ & 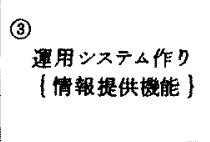 & 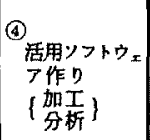 & 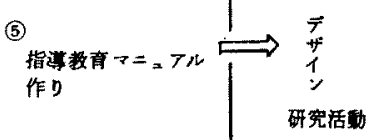 \\
\hline $\begin{array}{r}\text { 所在掅報システム } \\
\text { 收集绩舅システム } \\
\text { (制度) }\end{array}$ & 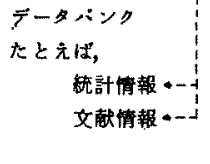 & 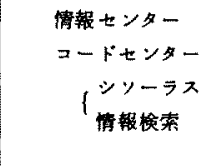 & $\begin{array}{c}\text { 提供シスデム } \\
\text { | 指高数育 } \\
\text { システム }\end{array}$ & $\bigsqcup_{\text {OUTPUT }}^{\text {提 }}$ \\
\hline
\end{tabular}

第 $1 \otimes$

クシステムが活動するための運用ンフトウェアの開発が， 当研究の主題であり，特に流通の観点から流通システム 化と相関関伯をむち，各企業の流通対策に奇与すること がネットワークシステム設計のための第一条件になると 考えられる。

\section{5. 瀻維衣料品業界における流通情報活動の 現状}

流通システム化においても, 織維衣料品業界に展開さ せる場合には，当業界の現状を把握，分析した上で設計 がなされてきている。

ネットワークの構築においても，単に器だけのネット ワークシステムを当業界においてからでは, 種々の不都 合が生じ，効果的な運用成果が得られないばかりか, 各 種批判のみに終るやも知れない。その意味において，情 報利用に関する業界の赛態，情報に対する考え万，情報 利用におけるフィロソフィ，情報システムとの関連事象 等，当業界における現状分析を十分行なう必要があるう。 われわれはこの対策として，情報活動心関するアンケ 一ト調查を，またその内容を質的に補足するためにイン タビュ一調査を行なってきた。しかし当策界の流通情報 ネットワークの必要性の度合ほど，情報利用の寒は獎は り上っておらず，個別企業の籍用の中で考えられている
場合㱙多いのには，いささか当業界の流通システム化の 将来に対して暗い影を感ぜしめる。

$$
\text { 6. ネットワークシステムの設棓 }
$$

このような当業界におけるネットワークシステムの搆 勧のための設計は前述における対象に対してなされるが， 現時点にお゙いて概要設計を行なうと次の通りである。

1）情報の体系化（データバンク）

情報センターは情報ブールをもつ，情啹機関である。 情報の必要性から各企業は情報をほしがり，さがしもと めるが，いざどのような情報をどのような情報分類で収 集活用されているのかと聞いてみても，その回答に明確 なものが表われてこない。このため同種の情報収集活用 に対する重複投資され，情竍利用のためのノウハウ警楀 が各個人のみにしかなされず，怪験至上主䔐的なしくみ を作りあけ，企業の組織力として生かされていないとい う結果を生んでしまうようである。

我々はその目的のべースとなる当業界の情報体系を作 りあげ，その体系に徒って情報とブールするデータハン クシステムを作るべきであると主張し，作菜を進めてい 万。

たとえば，情報体系の例をあげると次のようなをのが 考光られる。 


\section{流通情報項目 (広義)}

（1）社会一般情報

国際䋊済，海外企業输出入関保，政府政策，法的規制， 社会情勢, 社会梳計, 経済観椡, 景気動向, 海外ファッ ション動向，その他

（2）消費者一般情報

消費性向, 消費構造, 睡買心理, 消費者智好, 風俗レシ 十一, 街行動, 消費者運動

（3）释営計画情報

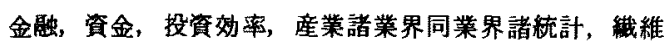
品目別，地域別，用途別諸統計，関連企業，提携先状況， 同業者経営計画, 営業戦略, 競争者, 市場占有状況, 商 品展開，営業実績，経営技術，経営多角化，高度化>1 ディフ, 労㣫需給, 労働条件, その他,

（4）商品計画情報

色彩, バターン, デザイン等項向、素材, 品質, 染色加 工, 新規製品, 新規用途, その他

（5）生産活動情報

原材料供給事倩，生産㧍よび加工の機材，生産及び加工 の技行, 生産コスト, その他

（6）物流一般情報

物流施設，社会資本関俰，渝送手段，荷役器機，物流二 ス卜，運筫体系，流通在庫状況，交通事情，その他

（7） 眅売・マーケティング情報

取引先信用状況，眅壳経路，眅売立地，取引条件，肘売 洒格, 店頭状況, 売筋, 商品带留状況, 肘壳催事, 眅売 促進技術, 新規顧客, 潜在需要, 眅売手段, 眅促活動, 宣伝活動，季節，天候条件，その他

2）情報収集ネットワークシステム

ネットワークの構造の一つに, 情報センタ一に情報を ブールするための情報収集構造が考えられる。

これには二つのとらえ方があり，一つはとにかく潜在 顕在をとわず，現在ある情報を結集させるしくみである。 これには当業界に拉いて情報収集に扔ける制度が考えら れる。正当なる企業の自由競争を乱さない情報，また業 界として進むべき方向付けに対して必要とする情報等住， 各企業が情報提供義務をもつという上うな制度である。 それから情報センターのスタッフによる情報収集活動機 能も大切な構造である。

二つ目は，現在存在するものだけの情報流通では解決 し得ない場合，すなわちある目的から必要情報が生れる 場合，その情報は創り出さなけ扎ばならない。の種の 情報は大変貴重な情報であり，なかなか情報としてとら えるのはむずかしいものであるが，特にこの問題に関し ては，業界各企業が情報センターを中心に結集し，相互 協業化のもとに対策を練らなばならない。ましてこの種
の情報において，企業間の暨を作り，情報目かくし競争 になったのでは，短期的には個別企業へースで措監し得 ても，業界全体の長期的な対策には絶対になり得ない。

このような業界各企業が一政協力のもとに行なう情報 収集ネットワークシステムは，倩報とは収集競争よりも， 利用活用競争が，より企業競争力の强化，また業稌各企 業の国際的競争下におけるレベルァッブになりうること を示唆している。

3）情報センターの設立

なんといってもネットワークの中心情報せンターで あり，このネットワークシステムを生かすもころすも，

業界各企業の情報センターの利用活用度合であるといえ る。

それではこの情報センターの機能はどのようなものが 考えられるであるうか。

もちろん情報センターのみで，すべての機能が発揮さ れるものではない。情報ネットワークとは情報センター と，各企業との相互ネットワークだけではなく，すでに 存在する調查会社と称される情報サービス業者, 情報関 連事業をよく実施している業界各舼団体，乙の他業界企 業をとりまく関連企業，さらに政府の業界関連機関が， 十分なネットワークに組まれていなければ、情報センタ 一はその機能を発揮することができないであるう。

その機能分類を行なえば，次のように考えられる。

(1) 情報の提供 (情報自体)

(2) 情報の娭索提供（情報の所在）

(3) 情報の分析加工（シンクタンク）

(4) 情報にもとずく技衍相談( コンサルティング)

(5) 情報システム設計のコンサルティンク

(6) 情報に関する教育

(7) 関連機関とのネットワーク(スイッチング)

(8) その他

4) 情報運用（提供）ネットワークシステム

情報センターが設立され，収集ネットワークができ， 情報がプールされたとしても，運用されなければ，何の 意味もない。

いままでの情報利用に関する業界調査結果によっても， 情報が過多であり，意志決定するまでに大变な労力を伴 ならという事が良くいわれている。すなわち適正な情報 流通のしくみが必要なのである。

これには一つに，情報の体系化につづく票集コード体 系作り，またその情報を適格にピックアップするための シンーラス作り等を必要としている。このようなしくみ つまり情報利用のための運用ネットワークシステムは， 情報センターを中核とし，業界企業の指導的，また統括 的立場にある業界の団体組織，ならびにその活動がなけ 
れば，生きた情報活用ネットワークシステムとして機能 されない。

情報センターでは基本的な標準コード，シソーラスを 用意し，情報利用を促進する運用ネットワーク事莱の成 果は，この複合的ネットワークの形成にあるといえる。

5）情報活用のためのソフトウェア

次に情報活用のためのソフトウェアとはどのようなも のかを考えてみたい。情報とは何らかの形で意志决定に 利用されるが，谪正な意志决定をするためには，情報に 関する人間の能力が大いに要求される。

目的に浨じてタイムリ一な，また適格な意志決定をよ り促進するためのッールとして，次のようなソフトウェ アが必要になりはしないだろらか。

(1) 情報加工分析システム

(2) 情報検索システム

(3) 統計処理ブログラム

(4) 各種情報処理システム

このンフトウェフに関しては研究が不十分であり，ま だまだ検討不足である。クロスインダストリーの課題と して，次期研究の場にも延長して考えたいと思っている。 6）情報利用技術と教育事業

前項と相対するものでもあるが，現在の情報処理技術 (ソフトゥェア技術)でッールとなり得ないものはどう すべきであろうか。

これは情報利用者, つまり人間そのものの情報応用技 術の啸練しかない。その意味でこのネットワークを背景 に情報利用に関する教育事業が必要なのである。

大企業中小企業を問わず, 意志决定者の情報応用技術 に関するノウハウのレベルアッブがなされなければ，構 築したネットワークおよびデーターバンクの利用効泌は 上らず，結局は無用の長物と化してしまうのは必至であ
る。

そのために低費用で参加できる情報利用に関するセ ナ一，訓練，講演会等，情報センターが中心となってや らねばならない教育関係事業が提案される結果となるわ けである。

以上ここれから調查研究し，解决しなけ机ばならない 事ばかりであるが，社会的意義を考えると，必ずやらね ばならない研究課題であり，その第一步として織維衣料 品業界の流通情報ネットワークの椣策をめざす当方にと って，菜寒げての協力が必要であり，またお頳いする 何ものでもない。

\section{7.おわりに}

これでこの研究の内容が終った訳ではなく，現時点の 研㠰作業報告のアウトライン紹介として筆をおくが，当 莱界における流通情報ネットワークの研究活動は昭和 48 年 3月まで続けられる。

しかし総合的な流通情報ネットワークの研究は，标来 数ケ年かけて，昭和 50 年度以降を目標に続けられるテ 一マであり，また必要性からいっても䟽けられなければ ならない。今回揭载した設計内容は一时期の研究通程か ら生まれた発想であり，今后十分業界への適合性への飨 討と設計棈造および機能に対する亭付け理諭が十分考后 されなければならず, 今后, 流通システム開発センター における研究作業の大きな課題である。

䅈界各位に扰いてむ流通システム化の壁を打ち破り， より業界各企莱の総合的レベルアップのために流通情 報ネットワークの重要性を再検討して頂きたいものであ る。

(昭和 48 年 1 月 11 日受理) 